\title{
THE LAW AND ECONOMICS OF INSIDER TRADING
}

\author{
Frank J. Sensenbrenner ${ }^{*} \&$ Margaret Ryznar ${ }^{* *}$
}

\section{INTRODUCTION}

Insider trading is as common as it is illegal. ${ }^{1}$ The result is many high-profile insider trading cases stemming from government enforcement of the ban on insider trading. ${ }^{2}$ For example, Mark Cuban is the billionaire owner of the Dallas Mavericks franchise in the National Basketball Association and a regular star on the television show Shark Tank. ${ }^{3}$ Recently, he also became the star of a high-profile insider trading case after he sold his stake in a Canadian Internet company, Mamma.com, to avoid a $\$ 750,000$ loss. ${ }^{4}$

* Fellow, Paul H. Nitze School of Advanced International Studies at Johns Hopkins University. The authors would like to thank Rick Harris, Thomas H. McInish, and Kerry Pattenden.

** Associate Professor, Indiana University McKinney School of Law.

1. John C. Coffee, Jr., Law and the Market: The Impact of Enforcement, 156 U. PA. L. REV. 229, 264 (2007) (citing Illegal Insider Trading: How Widespread Is the Problem and Is There Adequate Criminal Enforcement?: Hearing Before the S. Comm. on the Judiciary, 109th Cong. 12 (2006) (statement of Christopher K. Thomas, President, Measuredmarkets, Inc.)) ("Testifying before the Senate Committee on the Judiciary on September 26, 2006, Mr. Christopher Thomas, the founder of Measuredmarkets, an economic consulting firm, presented data suggesting that more than forty percent of the mergers with a value of $\$ 1$ billion or more that were announced in the United States over the twelve-month period ending in early July 2006 were preceded by suspicious trading that appeared to be, in his words, 'deviant trading behavior."'); see also Michelle N. Comeau, Comment, The Hidden Contradiction Within Insider Trading Regulation, 53 UCLA L. REV. 1275, 1275-76, 1290-91 (2006) ("[T] he roughly 475,000 insider trades executed each year consistently net higher returns than the trades of ordinary investors. And the vast majority are simply ignored by the Securities and Exchange Commission, either because the trades were made for reasons other than the insider's confidential knowledge, or because the government simply could not prove otherwise.").

2. See Matthew Goldstein, Ex-Trader at SAC Fund Is Sentenced to 3 Years, N.Y. TIMEs, May 17, 2014, at B1 ("[T] he prison sentence, coupled with a $\$ 2$ million fine, was necessary to send a message to others on Wall Street that insider trading is not a trivial crime."); Peter Lattman \& Azam Ahmed, Hedge Fund Billionaire Is Guilty of Insider Trading, N.Y. TIMES, May 12, 2011, at A1 ("Mr. Rajaratnam ... sought out information that was confidential.... and illegally traded on it, a jury in Federal District Court . . . found[,] . . . convicting him on all 14 counts of securities fraud and conspiracy.").

3. Dina El Boghdady, Mark Cuban Is Cleared in SEC Case, WASH. Post, Oct. 17, 2013, at A16.

4. Id. 
The insider trading case the Securities and Exchange Commission ("SEC") brought against him dominated the media, highlighting the government's efforts to enforce the insider trading prohibition. ${ }^{5}$ Ultimately, however, the SEC failed to make its case that Cuban received confidential, material, nonpublic information that caused him to trade his Mamma.com stock. ${ }^{6}$

The Cuban case was not the first high-profile insider trading case that the government lost, ${ }^{7}$ and it certainly was not the first SEC setback. ${ }^{8}$ On the contrary, the high-profile defeat for the government in the Cuban case was a culmination of calls to Congress to reexamine the insider trading legislation, which had already been the target of criticism for being ambiguous. ${ }^{9}$

However, despite its high-profile losses, the SEC has committed to prosecuting insider trading: the agency has filed record numbers of insider trading actions in recent years, totaling hundreds of cases. ${ }^{10}$ Indeed, upon the SEC's loss of the Cuban trial, an agency

5. See id.; Ben Protess \& Lauren D'Avolio, Jury Rules for Cuban in Setback for S.E.C., N.Y. TIMES, Oct. 17, 2013, at B1.

6. See Protess \& D'Avolio, supra note 5, at B1.

7. Readers may recall the attempted insider trading prosecution of Martha Stewart. See Jeanne L. Schroeder, Envy and Outsider Trading: The Case of Martha Stewart, 26 CARDOZo L. REv. 2023, 2023 (2005).

8. Other failures include the fact that "[i]n the past two decades, two of the most significant instances of industry-wide misconduct were uncovered by academics, not the SEC." Jonathan G. Katz, Reviewing the SEC, Reinvigorating the SEC, 71 U. PITT. L. REV. 489, 495 (2010). Also, "[d]espite years of investigation, and the signing of the first memorandum of understanding between the SEC and a foreign country (Switzerland), the SEC never succeeded in cracking the mysterious case of insider trading conducted by unknown persons trading through an obscure Swiss bank, Ellis AG." Id.

In another celebrated case, Eliot Spitzer, then Attorney General of New York, exposed the widespread practice by mutual funds of permitting certain large traders to buy or redeem fund shares at that day's price, rather than the following day's price. Interestingly, Spitzer's case began with a secret tip from an industry source, who chose to go to a state Attorney General rather than to the official regulator, the SEC.

Id. at 496; see also Peter J. Henning, Should the SEC Spin off the Enforcement Division?, 11 TRANSACTIONS 121, 121-22 (2009) ("The SEC's mishaps range from failing to uncover a Ponzi scheme to a completely mismanaged insider trading investigation. There is even the possibility that SEC staff engaged in insider trading.").

9. Phyllis Lipka Skupien, What's at Stake for Insider Trading Prosecutions After U.S. v. Newman, 20 WESTLAW J. SEC. LiTIG. \& REG., no. 23, 2015, at 1, 2; see also Jonathan R. Macey, The Distorting Incentives Facing the U.S. Securities and Exchange Commission, 33 HARV. J.L. \& PUB. PoL'Y 639, 646 (2010) ("[T]he SEC in recent years has attempted to expand the contours of the law, which makes it easier for them to bring cases, and to keep the law vague by refusing to define insider trading.").

10. See Mitchell A. Agee, Friends in Low Places: How the Law Should Treat Friends in Insider Trading Cases, 7 ChaRLeSTON L. Rev. 345, 346-47 (2013); 2012 Year-End Securities Enforcement Update, GIBSON DUNN (Jan. 9, 2013), 
spokesman said, "While the verdict in this particular case is not the one we sought, it will not deter us from bringing and trying cases where we believe defendants have violated the federal securities laws."11 In the aftermath of the Cuban case, the SEC maintained that its chief concern was being able to prosecute insider trading cases. ${ }^{12}$

Much attention has focused on shoring up the legal framework on insider trading to increase the success of these prosecutions, ${ }^{13}$ but some attention should also be paid to the question of how to catch insider trading. An empirical analysis of insider trading helps with this task. Accordingly, Part I of this Article sets the legal framework and reviews the ongoing debate over insider trading, while Part II turns to an empirical examination of the impact of insider trading on market performance and price distortion.

Part II employs a data set generated from SEC litigation releases, using a series of time-stamped trades prosecuted by the SEC to generate data files for both daily trading and intraday trading intervals. This data provides a natural experiment to examine the effects of insider behavior as the prosecution provides an ex post identification of insider trading within the larger pool of liquidity trades. In all the cases, the defendants traded on the basis of inside information, contravening federal law. The defendants are either insiders-corporate officers who received private information in the course of their duties-or individuals who received information from corporate officers but do not have a duty to the corporation. Analyzing this data, this Article finds that these trades differ from surrounding trades in both trade-to-trade price impact and trade lot volume, information that should aid the government in identifying and prosecuting insider trading.

\section{THE CuRRENT LEGaL FrameWORK ON INSIDER TRADING}

While there are many ways of defining insider trading ${ }^{14}$ and several theories on which to prosecute it, ${ }^{15}$ insider trading is

http://www.gibsondunn.com/publications/Documents/2012YearEnd-SecuritiesEnforcement-Update.pdf; see also Miriam H. Baer, Choosing Punishment, 92 B.U. L. REV. 577, 610 (2012) ("[T]he SEC had always portrayed itself as a punisher where insider trading was concerned ....").

11. Protess \& D'Avolio, supra note 5, at B1.

12. See Peter Lattman \& Floyd Norris, S.E.C. Report Clears Agency in Mark Cuban Case, N.Y. Times, Oct. 1, 2011, at B4.

13. See, e.g., Edward Green \& Olivia Schmid, Duty-Free Insider Trading?, 2013 ColuM. BUS. L. REV. 369, 416-17.

14. Sanford Grossman, for example, defines informed traders as those traders who know "the true underlying probability distribution which generates a future price, and they take a position in the market based on this information." Sanford Grossman, On the Efficiency of Competitive Stock Markets Where Trades Have Diverse Information, 31 J. FIN. 573, 573 (1976). 
essentially when a corporate insider or another party in possession of proprietary, nonpublic information trades upon it.16 The insider trading legal framework deyeloped in an ad hoc way through rulemaking and court decisions, and is far from elegant, as outlined in this Part. However, plaguing it is the debate whether insider trading should even be illegal in the first place.

\section{A. Philosophical Framework}

Insider trading bans have been among the most controversial aspects of securities regulation since the SEC condemned the practice in the 1961 Cady Roberts case. ${ }^{17}$ Professor Henry Manne shortly thereafter published his famous book criticizing, on economics grounds, the decision to prohibit insider trading. ${ }^{18}$ Since Manne, there have been many people skeptical of insider trading bans, and for various reasons. ${ }^{19}$

Some people have suggested that insider trading does not hurt anyone. ${ }^{20}$ Others have suggested that insider trading does not necessarily harm the securities market. ${ }^{21}$ If there is no harm, it becomes difficult to justify the significant costs of enforcing bans on insider trading. ${ }^{22}$ And if there is no harm in insider trading, questions arise as to whether the multimillion dollar penalties from

15. Harry S. Gerla, Confidentiality Agreements and the Misappropriation Theory of Insider Trading: Avoiding the Fiduciary Duty Fetish, 39 U. DAYTON L. REV. 331, 332-33 (2015).

16. See generally J. Scott Colesanti, "We'll Know It When We Can't Hear It": A Call for a Non-Pornography Test Approach to Recognizing Non-Public Information, 35 HofsTRA L. REv. 539, 560-67 (2006) (discussing what information qualifies as nonpublic).

17. In re Cady, Roberts \& Co., 40 S.E.C. 907, 912 (1961); Stephen Clark, Insider Trading and Financial Economics: Where Do We Go from Here?, 16 STAN. J.L. BUS. \& FIN. 43, 45 (2010).

18. See Henry G. MANne, Insider Trading And the Stock Market (1966).

19. See Jonathan Macey, Getting the Word Out About Fraud: A Theoretical Analysis of Whistleblowing and Insider Trading, 105 MICH. L. REV. 1899, 192935 (2007) (cataloging various criticisms of a ban on insider trading).

20. For example, "it is far from clear whether [Martha] Stewart's trades were unlawful, let alone illegal, and it is hard to identify any harm her acts directly caused anyone." Schroeder, supra note 7, at 2023. Ultimately, "Stewart was not even charged, let alone convicted, of insider trading ...." Id.

21. See, e.g., Stanislav Dolgopolov, Insider Trading, Informed Trading and Market Making: Liquidity of Securities Markets in the Zero-Sum Game, 3 WM. \& MARY BUS. L. REV. 1, 55 (2012) ("Overall, the current level of insider trading appears to have no significant adverse effect on equity market makers, and any further tightening of insider trading regulation and additional enforcement is unlikely to increase liquidity of equity markets. However, completely freeing the modern financial marketplace from regulatory restrictions on insider trading may present substantial problems for all types of market makers, but it is not a foregone conclusion.").

22. See John C. Coates IV, Cost-Benefit Analysis of Financial Regulation: Case Studies and Implications, 124 YALE L.J. 882, 882 (2015) ("A movement is afoot to impose cost-benefit analysis (CBA) on financial regulation (CBA/FR)."). 
insider trading bans are primarily intended to make the federal government richer, akin to high-cost speeding tickets. ${ }^{23}$

Even if the justifications for insider trading bans are accepted, criticism has also targeted the enforcement of the bans. For example, there is the possibility of bias in enforcement of the laws. ${ }^{24}$ Furthermore, there are separate critiques regarding overregulation of the business environment generally, ${ }^{25}$ as well as criticism that white collar penalties have been steeply increasing in recent years. ${ }^{26}$

On the other hand, many have argued that insider trading should remain illegal. This group argues that bans on insider trading have lowered the costs of capital, strengthened capital market development, and encouraged economic growth. ${ }^{27}$ People have suggested that bans on insider trading have equalized the informational inequality between corporate insiders and public investors. ${ }^{28}$

Additionally, some commentators have noted that there are indeed costs to insider trading because the insider sells securities at an inflated price. ${ }^{29}$ Others have noted that there are real harms of insider trading to the investing public because once the value of a particular piece of privileged information is used, there is no more

23. See Sonia A. Steinway, Comment, SEC "Monetary Penalties Speak Very Loudly," But What Do They Say? A Critical Analysis of the SEC's New Enforcement Approach, 124 YALE L.J. 209, 211 (2014) ("Efforts to distribute funds to harmed investors have tapered off over time, such that the vast majority of sums collected are still deposited in Treasury's General Fund. This ensures that the SEC contributes more revenue to the government than any other independent agency.").

24. Joan MacLeod Heminway, Save Martha Stewart? Observations About Equal Justice in U.S. Insider Trading Regulation, 12 TEX. J. WomEN \& L. 247, 263 (2003).

25. See, e.g., Karen E. Woody, Conflict Minerals Legislation: The SEC's New Role as Diplomatic and Humanitarian Watchdog, 81 Fordham L. REV. 1315, 1316-18 (2012) (noting that Dodd-Frank even extends to regulating conflict minerals for ethical reasons). For the argument that tax incentives might be better solutions to certain corporate issues than regulation, see Margaret Ryznar \& Karen E. Woody, A Framework on Mandating Versus Incentivizing Corporate Social Responsibility, 98 MARQ. L. REV. 1667, 1690-94 (2015).

26. Donna M. Nagy, Reflective Essay, Criminalization of Corporate Law: The Impact of Criminal Sanctions on Corporate Misconduct, 2 J. BUS. \& TECH. L. 111, 111-12 (2007).

27. Robert A. Prentice, Behavioral Economics Applied: Loss Causation, 44 Loy. U. CHI. L.J. 1509, 1512 (2013); see also George W. Dent, Jr., Why Legalized Insider Trading Would Be a Disaster, 38 DEL. J. CoRP. L. 247, 247, 273 (2013) ("[A] stubborn minority still defends [insider trading] as an efficient method of compensating executives and spurring innovation.").

28. Stuart Charles GoldBerg, SEC TRAding REstrictions and REPORTING REQUIREMENTS FOR INSIDERS 43 (1973).

29. See, e.g., Urska Velikonja, The Cost of Securities Fraud, 54 WM. \& MARY L. REV. 1887, 1902 (2013) ("[I]nsider trading transfers value from public investors to insiders who sell their stock at inflated prices."). 
opportunity for others to profit from that information..$^{30}$ Additionally, insider trading imposes costs on public investors by "(1) systematically diverting value from public shareholders to insiders, and (2) undermining and distorting insiders' incentives to generate economic value, thereby reducing the size of the pie." 31

Among the most cited reasons for insider trading bans is the promotion of investor confidence in the markets. ${ }^{32}$ Similarly, the prohibition on insider trading explicitly intends to secure the integrity of the securities market. ${ }^{33}$ Finally, some people simply do not like the idea of insider trading without being able to pinpoint the reason, ${ }^{34}$ while others note a vision of the prohibition as a moralistic response to greed. ${ }^{35}$

Regardless of the debate, insider trading laws have existed in the United States for decades. Countries around the world have noted the impact of the ban on the integrity of the American securities markets and introduced similar laws based on the American legal framework. ${ }^{36}$

\section{B. Legal Framework}

Insider trading is illegal under American securities law. ${ }^{37}$ However, there is a lack of tidiness in insider trading law, ${ }^{38}$ which

30. Jonathan R. Macey, Insider Trading: Economics, Politics, and Policy 10 (1991).

31. Jesse M. Fried, Insider Trading via the Corporation, 162 U. PA. L. REV. 801, 806 (2014).

32. E.g., John P. Anderson, Greed, Envy, and the Criminalization of Insider Trading, 2014 UTAH L. REV. 1, 9.

33. See, e.g., 15 U.S.C. $\S 78 \mathrm{~b}(2012)$ (stating that one of its purposes is "to insure the maintenance of fair and honest markets"); Release No. 33-6239, 45 Fed. Reg. 60,410, 60,412 (Sept. 12, 1980) (noting that trading on misappropriated confidential information undermines investor confidence and the integrity of the securities market).

34. See, e.g., Stuart P. Green \& Matthew B. Kugler, When is it Wrong to Trade Stocks on the Basis of Non-Public Information? Public Views of the Morality of Insider Trading, 39 FORDHAM URB. L.J. 445, 484 (2011) (explaining the wide range of views on insider trading held by the public).

35. E.g., Donald C. Langevoort, "Fine Distinctions" in the Contemporary Law of Insider Trading, 2013 Colum. BUS. L. REV. 429, 429.

36. For a review of the development of insider trading law around the world, see Franklin A. Gevurtz, The Globalization of Insider Trading Prohibitions, 15 TRANSNAT'L L. 63 (2002).

37. 15 U.S.C. $\$ 78$ j (2012); 17 C.F.R. $\S 240.10 \mathrm{b5}-1$ (a) (2014) ("The 'manipulative and deceptive devices' prohibited by Section 10(b) of the Act (15 U.S.C. 78j) . . . include ... the purchase or sale of a security by any issuer, on the basis of material nonpublic information...."). But see Erik Luna, Prosecutorial Decriminalization, 102 J. CRIM. L. \& CRIMINOLOGY 785, 813 (2012) ("Consider, for instance, insider trading: Although a respectable argument can be made that it should be no crime at all, neither legislative nor prosecutorial decriminalization of insider trading has any chance in the current political environment."). 
has plagued it from the beginning. ${ }^{39}$ Originally, state corporate law regulated insider trading, with some grounding in common law fraud as well.40 Federal regulation under the 1934 Securities Exchange Act eventually superseded them. ${ }^{41}$

Modern day insider trading law has evolved from Section 10 and Rule 10b-5 of the Securities and Exchange Act of 1934, and grew due to SEC rulemaking and judicial interpretation under Section 10(b) -necessary because the application of Section 10 and Rule $10 \mathrm{~b}-5$ to insider trading cases is not immediately intuitive or obvious. ${ }^{42}$ Neither Section 10(b) nor Rule $10 \mathrm{~b}-5$ was cited in order to regulate insider trading until 1961.43

Section 10 makes it unlawful to "use or employ, in connection with the purchase or sale of any security ... any manipulative or deceptive device or contrivance in contravention of" rules promulgated by the SEC.44 Meanwhile, Rule 10b-5 under the Exchange Act makes it unlawful to "engage in any act, practice, or course of business which operates or would operate as a fraud or deceit upon any person, in connection with the purchase or sale of any security." 45

To facilitate enforcement, there are several theories under which an individual can be held liable for insider trading under Rule 10b-5.46 The existence of these various theories represents the continued expansion of the legal framework to address insider trading.

The first theory of insider trading holds that Section 10(b) of the Securities Exchange Act and Rule 10b-5 prohibit a corporate insider,

38. E.g., Sung Hui Kim, Insider Trading as Private Corruption, 61 UCLA L. REv. 928, 931 (2014) ("Federal insider trading law seems to be a theoretical mess.' According to the consensus view among experts, it is 'seriously flawed,' 'ill-defined,' 'inconsistent,' 'astonishingly dysfunctional,' 'enigma[tic],' and even 'an ass."').

39. See id. at 935.

40. See Stephen Bainbridge, The Insider Trading Prohibition: A Legal and Economic Enigma, 38 U. FLA. L. REV. 35, 37-38 (1986).

41. 15 U.S.C. $\$ 78 \mathrm{j}(2012)$.

42. See Bainbridge, supra note 40 , at 38 ; Heminway, supra note 24 , at 256 ("The nature of the prohibited conduct (manipulation, deception, and fraud) is not clearly defined in Section $10(\mathrm{~b})$ or Rule 10b-5, and neither 'insider trading' nor 'insider' is explicitly defined (or even mentioned) in these core operative provisions. The inevitable result of this construction of the existing regulatory system is that neither Section $10(\mathrm{~b})$ nor Rule $10 \mathrm{~b}-5$ provides clear interpretive or enforcement guidance."); Richard E. Myers II, Complex Times Don't Call for Complex Crimes, 89 N.C. L. REv. 1849, 1853 (2011) ("Insider trading is a textbook example of the process of creating crimes through delegation to an agency.").

43. Bainbridge, supra note 40 , at 38 .

44. Securities and Exchange Act of $1934 \S 10,15$ U.S.C. $\S \S 78 j-j-4$ (2012).

45. 17 C.F.R. $\S 240.10$ b-5(c) (2014).

46. See Gerla, supra note 15, at 332-33 (listing three different theories of liability for insider trading under Rule 10b-5). 
such as a corporate officer or director, from trading in the corporation's securities on the basis of material, nonpublic information about the corporation. ${ }^{47}$ This is the classical theory of insider trading.

The next theory expands insider trading liability by expanding who can be liable for insider trading. ${ }^{48}$ Under the misappropriation theory, a person is liable for trading on the basis of material, nonpublic information if he has obtained the information through deception practiced on the source of the information. ${ }^{49}$

Finally, tipper/tippee liability also expands the concept of liable parties to include people who receive a tip in the form of material, nonpublic corporate information and trade on it if the tipper is in breach of a fiduciary duty owed to the corporation by supplying the information and the tippee knows or should know of the tipper's breach of fiduciary duty. ${ }^{50}$ In other words, if the tippee receiving material, nonpublic information trades on such information, knowing that the tipper's disclosure of the information breaches a duty, then the tippee also violates federal securities laws.

Under this framework, therefore, it is a violation to be "(1) trading securities (2) on the basis of (3) material (4) nonpublic information (5) in violation of a duty of trust or confidence owed directly or indirectly to the corporation, the corporation's

47. United States v. Newman, 773 F.3d 438, 445 (2d Cir. 2014), cert. denied, 136 S. Ct. 242 (2015). In October 2015, the Supreme Court denied the petition for certiorari in the case. Newman significantly narrowed the definition of insider trading by requiring proof that an inside tip recipient knew the confidential information came from an insider and that the insider disclosed the information for a clear personal benefit. The result of the case was the overturning of two convictions for insider trading and dropped charges against others. Id.

48. Congress enacted the Stop Trading on Congressional Knowledge Act of 2012, or STOCK Act, to prevent members of Congress from being able to trade on material, nonpublic information received while in their government positions. Stop Trading on Congressional Knowledge (STOCK) Act of 2012, Pub. L. No. 112-105, 126 Stat. 291.

49. Id.; see also SIMON M. LORNe, ACQUisitions AND MERgers: Negotiated AND CONTESTED TRANSACTIONS § 1:23 (2010) ("Following acceptance of the theory by the Second, Seventh, Ninth, and, arguably, the Third Circuits and rejection of the theory by the Fourth and Eighth Circuits, in June 1997, the United States Supreme Court upheld the validity of the misappropriation theory as a means of fighting insider trading in United States v. O'Hagan."); Jeanne L. Schroeder, Taking Stock: Insider and Outsider Trading by Congress, 5 WM. \& MARY BUS. L. REV. 159, 182 (2014) ("Because the classic theory, as set forth in Chiarella and Dirks, does not cover many transactions that seem intuitively to be equally unseemly, the SEC and DOJ sought to develop an alternate theory of unlawful trading.").

50. Gerla, supra note 15, at 332-33; see supra note 47. 
shareholders, or the source of the information." 51 These elements have been subject to interpretation in extensive case law. 52

Critics contend that the legal framework on insider trading is dissatisfying, and note that " $[\mathrm{t}]$ he absence of a satisfying theory of insider trading law may have real-world consequences. Numerous lower courts as well as the Securities and Exchange Commission (SEC) have recently attempted to expand liability beyond what many thought to be the well-settled parameters established by the U.S. Supreme Court." 53

Indeed, the difficulty of drawing a line between illegal behavior and mere aggressive business behavior has resulted in a lack of a firm legal framework. ${ }^{54}$ While more cases have been pushing the boundaries of what violates Section $10(\mathrm{~b}),{ }^{55}$ some corporations have preferred to settle their cases with monetary payments instead of trials, which results in the lack of judicial interpretation of whether securities fraud actually occurred. ${ }^{56}$

There are several defenses to insider trading. ${ }^{57}$ One defense is to show that the person accused of insider trading acted without scienter. ${ }^{58}$ A reliance-based defense, meanwhile, attempts to demonstrate that "no market participant relied upon the defendant's omissions or misrepresentations in deciding to purchase or sell a security." 59

There are several mechanisms to enforce insider trading laws, including civil, criminal, and private. 60 In a criminal prosecution, an individual faces a maximum fine of $\$ 5$ million and up to twentyyears imprisonment, while a corporation may be subject to a maximum fine of $\$ 25$ million. ${ }^{61}$ "Criminal penalties may be imposed in addition to civil penalties and disgorgement." 62

51. Samer B. Korkor, Unexpected Commonalities: The Applicability of Bioethics Concepts to Insider Trading Law, 47 U.S.F. L. REv. 689, 692 (2013).

52. Id. at 692-93.

53. See Kim, supra note 38 , at 932 .

54. Green \& Kugler, supra note 34 , at 450 ("The law of insider trading ... makes fine distinctions between conduct that appears to be merely 'aggressive business behavior' and conduct that is illegal and potentially criminal.").

55. Joanna B. Apolinsky, The Boundaries of Fraud Under the Insider Trading Rules, 13 FLA. ST. U. BUS. REV. 1, 4 (2014).

56. Id. at $4-5$.

57. For an excellent background on these defenses, see Christopher A. Yeager et al., Securities Fraud, 51 AM. CRIM. L. REv. 1661, 1706-20 (2014).

58. Id. at 1706 .

59. Id.

60. See Panel: The SEC's Perspective, 2013 Colum. Bus. L. REv. 519, 539.

61. 15 U.S.C. $§ 78 f f(a)$ (2012); see also Allyson Poulos et al., Securities Fraud, 50 AM. CRIM. L. REv. 1479, 1549-50 (2013) (providing an overview of criminal penalties for insider trading).

62. Poulos et al., supra note 61, at 1549 (citations omitted) (first citing 15 U.S.C. $\S 77 \mathrm{t}(\mathrm{D})(2)(\mathrm{A}) \cdot(\mathrm{C})$; then citing $i d$. $\S 78 \mathrm{u}-1$ to -2 ; and then citing id. $\S 78 \mathrm{u}$ 2(e)). 
The SEC may bring a civil action for penalties. 63 The SEC generally seeks treble damages under the Insider Trading Sanctions Act of 1984,64 and its enforcement measures include equitable remedies such as injunctions, disgorgement, cease-and-desist orders, and trading bans against individuals. ${ }^{65}$ This represents an expansion of the remedies traditionally available to the SEC. During the first fifty years of SEC enforcement of insider trading laws, the agency brought limited enforcement actions against corporate defendants, with the main available remedies being courtordered injunctions and disgorgement. ${ }^{66}$ Since then, the penalties collected by the SEC have been increasing steadily in size and frequency, with penalties over $\$ 100$ million now common. ${ }^{67}$

The 1934 Act contains Section 20A, which provides for liability to contemporaneous traders for insider trading, ${ }^{68}$ and Section 21A, which sets out civil penalties for insider trading. 69 Private actions are authorized by Section 20A(b)(3) of the 1934 Act, which establishes an express right to recover against any controlling person of a tipper or trader. ${ }^{70}$ Meanwhile, Section 21A allows the SEC to bring civil actions against insider traders. ${ }^{71}$

The Department of Justice pursues criminal enforcement of insider trading laws. ${ }^{72}$ Criminal penalties are established under the Federal Sentencing Guidelines. ${ }^{73}$ Departures from the sentencing

63. 15 U.S.C. $\S 78 \mathrm{u}-1(\mathrm{a})(1)$. For an excellent overview of civil penalties on insider trading, see David M. Becker, What More Can Be Done to Deter Violations of the Federal Securities Laws?, 90 TEX. L. REV. 1849 (2012). For an overview of the SEC investigation and enforcement process, see Danné L. Johnson, SEC Settlement: Agency Self-Interest or Public Interest, 12 FORDHAM J. CORP. \& FIN. L. 627 (2007).

64. 15 U.S.C $\S 78 \mathrm{u}-1(\mathrm{a})(2)$.

65. Dante Figueroa, Insider Trading and Other Securities Frauds in the United States: Lessons from Chile, 3 Mich. J. PRIV. EQUITY \& Venture CAP. L. 165,176 (2014).

66. Nagy, supra note 26, at 111.

67. Id. at $111-12$.

68. 15 U.S.C. $\S 78 \mathrm{t}-1(\mathrm{a})$.

69. Id. $\S 78 \mathrm{u}-1(\mathrm{a})$.

70. Id. $\S 78 \mathrm{t}-1(\mathrm{~b})(3)$.

71. Id. § $78 \mathrm{u}-1(\mathrm{a})(1)$.

72. See Preet Bharara, Securities Fraud, U.S. DEP'T oF JUST., http://www.justice.gov/usao/priority-areas/financial-fraud/securities-fraud (last updated July 8,2015 ) (discussing the number of insider trading convictions since October of 2009).

73. Convictions for violating the 1934 Act lead to sentencing in accordance with section 2B1.1 of the United States Sentencing Guidelines ("Guidelines"). Poulos et al., supra note 61, at 1550. Violations start at a base offense level of six under section 2B1.1. U.S. SENTENCING Guidelines ManUal $\S 2 B 1.1(a)(2)$ (2013). The base offense level is seven if the offense for which the defendant was convicted has a statutory minimum imprisonment term of twenty years or more. Id. $\S 2 \mathrm{~B} 1.1(\mathrm{a})(1)$. Convictions for insider trading under the 1934 Act also lead to sentences in accordance with section $2 \mathrm{Bl} 1$ of the Guidelines. Id. app. A. Courts increase this offense level by the number of levels from the table in 
guidelines occur, ${ }^{74}$ and some sentences have been harsh. ${ }^{75}$ Although Congress had promulgated the Federal Sentencing Guidelines in order to achieve sentencing consistency in federal criminal cases, 76 recent high-profile insider trading cases have produced a range of sentences noteworthy for their disparity. ${ }^{77}$

Criminally, insider trading ... is punished according to the gains received by the insider as a result of the trading. In other words, the greater the gains, the longer the sentence. The potential punishment is high, as the already harsh penalties under the Insider Trading and Securities Fraud Enforcement Act of 1988 were increased in 2002 to possible fines of up to $\$ 5$ million for individuals and prison sentences of up to twenty years. Given its only mixed success in prosecuting criminal insider trading cases, the government has every incentive to make examples out of those insiders that it is actually able to convict by seeking longer sentences. ${ }^{78}$

The largest penalty for insider trading was $\$ 1.8$ billion against SAC Capital- $\$ 900$ million in connection with the criminal case and $\$ 900$ million in connection with the settlement of the civil forfeiture

section 2B1.1 corresponding to the loss resulting from the offense. Id. at $\S 2 \mathrm{~B} 1.1(\mathrm{~b})(1)$.

74. Rajat Gupta, a high-profile insider trading defendant, is serving two years in prison for passing inside information to hedge fund manager Raj Rajaratnum that allowed Rajaratnum to make millions in illegal trades in less than two days. Todd Haugh, Sentencing the Why of White Collar Crime, 82 FORDHAM L. REv. 3143, 3144 (2014). The government had asked for ten years, and the Federal Sentencing Guidelines called for between six-and-a-half and eight years. Id. at 3145. Rajaratnum received an eleven-year prison sentence. Id.

75. See Samuel W. Buell, Is the White Collar Offender Privileged?, 63 DukE L.J. 823, 834 (2014) ("As much as the first-generation statutes and guidelines constrained judges from case-specific leniency, channeled more white collar cases toward imprisonment, and abolished parole, later legislation and amendments in the 1990 s and early 2000 s turned white collar sentencing in federal court into a harsh business.").

76. Paul J. Hofer \& Mark H. Allenbaugh, The Reason Behind the Rules: Finding and Using the Philosophy of the Federal Sentencing Guidelines, 40 AM. CRIM. L. REv. 19, 20 (2003); see also S. REP. No. 98-225, at 38-39 (1983).

77. Mark D. Harris, Anna G. Kaminska \& Samantha Springer, The Current State of White-Collar Sentencing, 26 FED. SENT'G REP. 1, 3 (2013).

78. Nicholas P. Pellicani, Note, No Pain, No Gain: The Criminal Absence of the Efficient Capital Markets Theory from Insider Trading Sentencing, 84 ST. JOHN's L. REV. 1057, 1059-60 (2010); see also JONATHAN R. MACEY, INSIDER TRADING: ECONOMICS, POLITICS, AND POLICY 6 (1991) ("Where probability of detection is low, very high penalties are necessary to deter potential lawbreakers."); Becker, supra note 63, at 1849 ("This Article suggests that there is probably little to be gained from increasing sanctions and that the SEC probably would be better served by focusing its efforts on increasing the likelihood that certain violations are punished and by redoubling its efforts to move more quickly."). 
action. ${ }^{79}$ The $\$ 900$ million criminal fine imposed by the court "exceeded a Sentencing Guidelines range that was, in turn, based on all of the illicit profits gained and losses avoided resulting from all of the insider trading alleged in the Indictment."80 Settlements may often include a corporate monitor. 81

Due to the deep pockets of corporations relative to individuals, the SEC has a financial incentive to pursue actions against companies rather than individuals within those companies. 82 However, "[m]arket manipulation and insider trading enforcement actions tend to target individuals and yield smaller fines and disgorgements. Median fair funds in these cases were $\$ 1.4$ million (\$2.9 million mean) and $\$ 2.6$ million ( $\$ 6.7$ million mean), respectively, compared with the overall median of $\$ 16.5$ million (\$59.5 million mean)." 83

\section{THE EMPIRICS OF INSIDER TRADING}

While the legal approach to insider trading continues to develop, economists have been studying insider trading as well. They have looked at the price and volume impact on the day of the insider trading. ${ }^{84}$ This Article contributes to this literature by testing the impact of insider trading on market performance and price distortion to aid enforcement of insider trading laws.

\section{A. The Economic Literature}

According to Grossman, insider traders are a subset of a larger category of informed traders. 85 Informed traders are those traders who know "the true underlying probability distribution that generates a future price." 86 They therefore trade upon this information and impound the information into market prices. 87

79. Press Release, U.S. Attorney's Office, S.D.N.Y., Manhattan U.S. Attorney Announces Guilty Plea Agreement with SAC Capital Mgmt. Cos. (Nov. 4, 2013), http://www.justice.gov/usao/nys/pressreleases/November13 /SACPleaPR.php.

80. Press Release, U.S. Attorney's Office, S.D.N.Y., SAC Capital Mgmt. Cos. Sentenced in Manhattan Fed. Court (Apr. 10, 2014), http://www.justice.gov /usao-sdny/pr/sac-capital-management-companies-sentenced-manhattan-federal -court-insider-trading.

81. Cristie Ford \& David Hess, Can Corporate Monitorships Improve Corporate Compliance?, 34 J. CORP. L. 679, 680 (2009).

82. MACEY, supra note 78 , at 651 .

83. Urska Velikonja, Public Compensation for Private Harm: Evidence from the SEC's Fair Fund Distributions, 67 STAN. L. REv. 331, 355 (2015).

84. See infra notes 96-102 and accompanying text.

85. Sanford J. Grossman, An Analysis of the Role of "Insider Trading" on Future Markets, 59 J. Bus. S129, S130 (1986).

86. Sanford Grossman, On the Efficiency of Competitive Stock Markets Where Trades Have Diverse Information, 31 J. FIN. 573, 573 (1976).

87. Efficient market theory, in its strong form, holds that security prices "fully reflect" all available information on a company's fundamentals. See 
Market microstructure theory, which is concerned with the exchange of securities, notes that traders in the market should react to the presence of an insider trader to offset the costs of potential predation. ${ }^{88}$ Predation can be conceived of as the difference between the trading price of the asset and the true price of the asset that only the informed trader knows. This scenario is referred to as adverse selection, where one party is privy to fundamental information on the value of a transaction of which the other party is unaware. ${ }^{89}$ As a result, Lawrence Glosten and Paul Milgrom posit that certain counterparties will increase the cost of trading by raising the bid-ask spread (a measure of the cost of trading), ${ }^{90}$ an assertion also made by David Easley and Maureen O'Hara. ${ }^{91}$

Under certain market conditions where there is a specialist, 92 statistical methods can be built that could detect anomalous trades. This is to be distinguished from a dealer market, where due to the ability of the insider to split orders across dealers (and exchanges), a party may not detect any aberrant behavior that may be the result of insider trading.

According to Albert Kyle, insider traders will trade over a prolonged period to extract maximum value from their private information. ${ }^{93}$ Therefore, one should expect insiders to trade repeatedly and in a way that does not cause their information to be exposed, which would erode their competitive advantage, as well as potentially leave them open to prosecution.

Eugene F. Fama, Market Efficiency, Long-Term Returns, and Behavioral Finance, 49 J. FIN. ECON. 283, 284 (1998).

88. Maureen O'Hara, High Frequency Market Microstructure, 116 J. Fin. EcoN. 257, 260 (2015).

89. Examples of adverse selection include a high-risk patient purchasing insurance or a person purchasing a used car (the seller knows more about the used car's quality than the buyer). See generally Mark A. Hall, The Competitive Impact of Small Group Health Insurance Reform Laws, 32 U. MICH. J.L. REFORM 685, 687 (1999) (providing an explanation of adverse selection in the health insurance market).

90. Lawrence R. Glosten \& Paul R. Milgrom, Bid, Ask and Transaction Prices in a Specialist Market with Heterogeneously Informed Traders, 14 J. FIN. ECON. 71, 72 (1985).

91. David Easley \& Maureen O'Hara, Price, Trade Size, and Information in Securities Markets, 19 J. FIN. ECON. 69, 70 (1987).

92. The specialist is an intermediary between buyers and sellers with a monopoly on trading in shares of a certain company. See generally J. Scott Colesanti, Not Dead Yet: How New York's Finnerty Decision Salvaged the Stock Exchange Specialist, 23 ST. JoHN's J. LEGAL COMMENT. 1 (2008) (explaining the history and role of stock exchange specialists). In exchange for that privilege, the specialist also has an obligation to continually offer prices for trading. Id. at 2-3. The specialist was the dominant market structure for the New York Stock Exchange prior to the early 2000 s. Id. at 1, 10-11.

93. Albert S. Kyle, Continuous Auctions and Insider Trading, 53 ECONOMETRICA 1315, 1333 (1985). 
One would expect insiders to use limit orders ${ }^{94}$ to avoid detection, as they have a lesser price impact, and to trade over a period of several days in order to extract the maximum rent from their monopoly information. Utpal Bhattarchaya and Hazem Daouk find that insider trading increases the cost of capital and alters the capital rationing function of the markets, ${ }^{95}$ so failure to regulate markets efficiently may decrease the ability of capital markets to perform capital allocation, arguably the most important welfare function of markets.

Lisa Meulbroek's is the first empirical research paper to investigate the daily impact of insider trading on share prices. ${ }^{96}$ She compiles private SEC files with publicly available data and news reports to profile and examine insider trading behavior in cases prosecuted from 1980 to 1989.97 She tests for both abnormal price movements and abnormal trading volume on the days insiders are active in the market and finds that price movements on the days that insiders trade are almost half (forty-seven percent) of the size of price movements on days when the news is publicly disclosed. 98

Meulbroek finds an average run-up of $3.06 \%$ on the first day of insider trades, and a cumulative abnormal return relative to the market of $6.85 \%$ on all the days insiders trade. ${ }^{99}$ This provides good support for the notion that information is leaking into the market and impounded in price. This is echoed by Gregg Jarrell and Annette Poulson, who find a forty percent run-up prior to merger announcements, which they attribute to insiders. 100 Meulbroek also finds that insiders provide the marginal volume that distinguishes insider trading days from noninsider trading days. ${ }^{101}$ She notes that

94. Two forms of orders characterize trading: a limit order, where the buyer or seller states that she will buy or sell a certain number of shares at a certain price and the order only executes if another party meets that price (and may not execute in full); and a market order, where a buyer or seller will buy or sell a certain number of shares at whatever price the market will bear. See Fast Answers: Limit Orders, U.S. SEC. \& ExCHANGE CoMmission, http://www.sec.gov /answers/limit.htm (last modified March 10, 2011); Fast Answers: Market Orders, U.S. SEC. \& EXCHANGE COMMISSION, http://www.sec.gov/answers /mktord.htm (last modified March 9, 2011).

95. Utpal Bhattacharya \& Hazem Daouk, The World Price of Insider Trading, 57 J. FIN. 75, 78 (2002).

96. See Lisa K. Meulbroek, An Empirical Analysis of Illegal Insider Trading, 47 J. Fin. 1661, 1661 (1992).

97. Id. at 1665 .

98. Id. at 1675,1678 .

99. Id. at 1675 .

100. Gregg A. Jarrell \& Annette B. Poulsen, Stock Trading Before the Announcement of Tender Offers: Insider Trading or Market Anticipation?, J.L. ECON. \& ORG. 225, 235, 244 (1989).

101. Meulbroek, supra note 96, at 1688-1689. 
since insider trading drives abnormal volume, insider trading leads to abnormal returns. 102

Cornell and Sirri examine an insider trader ring, as do Chakravarty and McConnell. In Cornell and Sirri's case study, the ring consists of a group of insiders trading in advance of a merger announcement, 103 while Chakravarty and McConnell focus on arbitrageur Ivan Boesky's insider trading in Carnation shares. ${ }^{104}$ Cornell and Sirri determine that insider trading's effect in the acquisition of Campbell Taggart was complex. ${ }^{105}$

Price was affected and volume increased, but contrary to Meulbroek's findings, Campbell Taggart's liquidity improved. ${ }^{106}$ This is unexpected in that an aggressive insider ring would lead specialists to protect themselves through changes in the spread, ${ }^{107}$ and thus liquidity would be expected to decrease. Cornell and Sirri attribute these seemingly contradictory results to the presence of noise traders, who are defined as falsely informed traders. 108

Falsely informed traders can be defined as those traders who believe that they are trading on superior information and analysis but in fact do not have any advantage over other traders. Cornell and Sirri cite technical traders ("chartists") as a classic example of falsely informed traders. ${ }^{109}$ They argue that the specialist's problem dissipates when he can match falsely informed traders and informed traders, as the informed traders are counterparties to the falsely informed trades and the specialist is not subject to inventory effects. ${ }^{110}$

This coincides with Anat Admati and Paul Pfleiderer's conclusion that informed traders increase activity when noise traders are present in the market to take advantage of increased

102. Id. at 1688 .

103. See Bradford Cornell \& Erik R. Sirri, The Reaction of Investors and Stock Prices to Insider Trading, 47 J. FIN. 1031, 1031 (1992).

104. See Sugato Chakravarty \& John J. McConnell, An Analysis of Prices, Bid/Ask Spreads, and Bid and Ask Depths Surrounding Ivan Boesky's Illegal Trading in Carnation's Stock, 26 FIN. MGMT. 18, 18 (1997) [hereinafter Chakravarty \& McConnell, Carnation's Stock]; Sugato Chakravarty \& John J. McConnell, Does Insider Trading Really Move Stock Prices?, 34 J. FIn. \& QuANTITATIVE ANALYSIS 191, 191 (1999) [hereinafter Chakravarty \& McConnell, Insider Trading].

105. Cornell \& Sirri, supra note 103 , at 1032, 1054.

106. Id. at 1032.

107. See, e.g., Glosten \& Milgrom, supra note 90 , at 91 .

108. Cornell \& Sirri, supra note 103 , at 1055. Noise traders are differentiated from liquidity traders in that noise traders believe they are trading on special information. Id. at 1032; see also J. Bradford De Long et al., Noise Trader Risk in Financial Markets, 98 J. PoL. ECON. 703, 706 (1990).

109. Cornell \& Sirri, supra note 103, at 1032.

110. See id. at 1054 . 
liquidity and better disguise their activities in the market.111 Therefore, Glosten and Milgrom's finding 112 may not hold because insiders, not the specialist, prey upon falsely informed traders.

Cornell and Sirri's case study is distinct from other studies in that the insider ring purchases a substantial proportion of traded shares. In their study, insider purchases constitute twenty-nine percent of the total volume and represent a significant increase in volume. ${ }^{113}$ Cornell and Sirri attribute all the effects in their study to the presence of insiders and falsely informed traders because the target company, Campbell Taggart, did not exhibit any confounding behavior that could drive abnormal volume (such as news stories speculating on its potential as a merger target). ${ }^{114}$ Through tracking short interest (unchanged), volume, and the share price of Anheuser-Busch (the acquirer), Cornell and Sirri conclude that the only informed traders present are the insider traders. ${ }^{115}$

Chakravarty and McConnell find a weak link between insider trading and subsequent stock prices, showing both a lagged correlation between Boesky's purchases in the market and subsequent prices-with the strongest significance displayed in the link between Boesky's purchases and the stock price two hours later-and a link between Boesky's buying and contemporaneous price increases. ${ }^{116}$

However, price increases immediately after Boesky's purchases may just be a liquidity effect, as any large trader aggressively buying in the market will push up the price and is thus not an effect per se of insider trading. Boesky's trading did not affect bid-ask spreads, the standard measure of trading costs, 117 similar to the trading examined by Cornell and Sirri. ${ }^{118}$ Also, although Boesky contributed to the increased volume on days he traded, he was responsible for only half of it, with the other half potentially coming from falsely informed traders or momentum traders. ${ }^{119}$

By using time stamped trades and segmenting their sample into Michael Barclay and Jerold Warner's categories, ${ }^{120}$ Chakravarty and McConnell discover that the Boesky trades that correlated with price movements are the larger trades. ${ }^{21}$ They further conclude that since insider trading may be beneficial, as it assists in price

111. See Anat R. Admati \& Paul Pfleiderer, A Theory of Intraday Patterns: Volume and Price Variability, 1 REV. FIN. STUD. 3, 5, 33 (1988).

112. Glosten \& Milgrom, supra note 90, at 97-98.

113. Cornell \& Sirri, supra note 103 , at 1034.

114. See id. at 1036.

115. Id. at $1036-37$.

116. Chakravarty \& McConnell, Carnation's Stock, supra note 104, at 21, 25.

117. Id. at 29.

118. Cornell \& Sirri, supra note 103 , at 1054 .

119. Chakravarty \& McConnell, Carnation's Stock, supra note 104, at 29.

120. Id. at 27.

121. Id. 
discovery, so long as spreads do not change, as in this case, there is no adverse selection component. ${ }^{122}$ However, Chakravarty and McConnell were unable to discern whether Boesky's trading spurred the price run-up, or whether he chose to trade on days after observing such an increase in prices. ${ }^{123}$

Chakravarty and McConnell reprise the study but with the important inclusion of trade direction through the use of the Lee and Ready algorithm. ${ }^{124}$ They find that Boesky's trades (buys) in Carnation did not have a different impact than other buys and thus conclude that a large component of price impact in that case was due to overall trade imbalance, as opposed to the presence of an informed trader in the market. 125

Chakravarty and McConnell also estimate Meulbroek's and Cornell and Sirri's regressions on the Boesky data, and discover that when adjusting their methodologies for trade direction, insider trading is statistically no different from a trade in the similar direction. ${ }^{26}$ They verify with the Boesky data Meulbroek's contention that higher returns exist on insider trading days than on days with no insider trading or public news announcements. 127 Chakravarty and McConnell notably state that their critical assumption is that all non-Boesky trades are uninformed. ${ }^{128}$

Raymond Fishe and Michael Robe discuss the impact of insider trading in advance of a news column. 129 This can be differentiated from the other cases inasmuch as the insiders' trading pattern is relatively regular: they trade the day prior to public disclosure of the information. Fishe and Robe use spreads and depth in the limit order book as key metrics to measure the impact of illegal insider trading, ascertaining that when an insider is present in the market, depth shrinks in both dealer and specialist markets but spreads increase only under specialist markets. ${ }^{130}$

122. Id. at $19,32-33$.

123. Id. at 21 .

124. Chakravarty \& McConnell, Insider Trading, supra note 104, at 192, 196, 199; Charles M.C. Lee \& Mark A. Ready, Inferring Trade Direction from Intraday Data, 46 J. FiN. 733, 736-37, 745 (1991) (discussing that their "Lee and Ready" algorithm partitions trades into buyer-initiated and seller-initiated, based on the party that created the transaction).

125. Chakravarty \& McConnell, Insider Trading, supra note 104, at 208.

126. Id. at 193; see also Cornell \& Sirri, supra note 103, at 1032, 1055; Meulbroek, supra note 96 , at 1663 .

127. Chakravarty \& McConnell, Insider Trading, supra note 104, at 205; see also Meulbroek, supra note 96, at 1696.

128. Chakravarty \& McConnell, Insider Trading, supra note 104, at 201.

129. Raymond P.H. Fishe \& Michel A. Robe, The Impact of Illegal Insider Trading in Dealer and Specialist Markets: Evidence from a Natural Experiment, 71 J. FIN. ECON. 461, 462 (2004).

130. Id. at 463,486 . Fishe and Robe find that "only ask depth changes significantly." Id. at 462,486 . As their data is comprised solely of purchases of shares, this may be a natural conclusion. Id. at $462,467$. 
These results substantiate Glosten and Milgrom's model.131 They find that volume increases substantially only after the insiders are present in the market and attribute this to the presence of falsely informed traders. ${ }^{132}$ The insiders are only responsible for a marginal increase in volume $(9.2 \%),{ }^{133}$ which seems to suggest that either the information on which the insiders trade leaks or falsely informed traders are goaded into the market after observing a spike in price and volume. Fishe and Robe use a control group of equities in which information was available to the insiders but they did not trade, and find that normal price, volume, and spread patterns prevail. 134

In summary, Cornell and Sirri, Meulbroek, and Chakravarty and McConnell all identify a significant price and volume impact on the day of the insider trading, but do not have sufficiently granular data to identify whether the increased volume and price are spurred by insider trades. ${ }^{135}$ In addition, each of these studies uses aggregated data (for Cornell and Sirri and Meulbroek, daily data, ${ }^{136}$ for Chakravarty and McConnell, hourly data ${ }^{137}$ ), leaving unanswered the question as to how insider trades immediately impact prices and volumes. Furthermore, all the studies with the exception of Meulbroek's are comprised solely of insiders purchasing shares, ${ }^{138}$ which may provide an unrepresentative sample of data with which to make blanket conclusions as to the effect of insider trading. Meulbroek's sample is driven by speculation on merger announcements, which she shows to have a higher abnormal return than the impact of other information disclosed into the marketplace. 139

These inconsistent explanations merit further study, as Chakravarty and McConnell wrote. ${ }^{140}$ The question that arises is whether results from a small population (with one insider trader or a small ring) are valid amongst a larger sample or if the results are driven by idiosyncratic attributes of the trades (e.g., a trader accounting for a large proportion of trading volume). ${ }^{141}$

131. Glosten \& Milgrom, supra note 90 , at 72-73.

132. Fishe \& Robe, supra note 129 , at 463.

133. Id.

134. Id.

135. See Chakravarty \& McConnell, Carnation's Stock, supra note 104, at 21; Chakravarty \& McConnell, Insider Trading, supra note 104, at 191-209; Cornell \& Sirri, supra note 103, at 1045-46; Meulbroek, supra note 96, at 1675.

136. Cornell \& Sirri, supra note 103, at 1035; Meulbroek, supra note 96, at 1676-77.

137. Chakravarty \& McConnell, Carnation's Stock, supra note 104, at 23.

138. Id. at 18; Cornell \& Sirri, supra note 103, at 1032; Meulbroek, supra note 96 , at $1662-63$.

139. Meulbroek, supra note 96 , at 1680.

140. Chakravarty \& McConnell, Insider Trading, supra note 104, at 208.

141. See id. at 191-209. 


\section{B. Empirical Examination}

This Article tests the impact of insider trading on market performance and price distortion. It examines whether changes can be measured that capture the presence of an insider in the market and how the market responds to the insider's activity. Existing literature contends that in the presence of an insider, market participants will increase the spread to compensate for adverse selection, and this may lead to increased price movement on a tradeby-trade level as market orders absorb this increased cost. ${ }^{142}$

The data is analyzed on macro (daily) and micro (intraday) levels. Employing a dataset generated from SEC litigation releases, ${ }^{143}$ this Article uses a series of time-stamped trades prosecuted by the SEC to generate data files for both daily trading and intraday trading intervals. This data provides a natural experiment to examine the effects of insider behavior as the prosecution provides an ex post identification of insider trading within the larger pool of liquidity trades.

In all the cases, the defendants traded on the basis of inside information, contravening federal law. The defendants either are insiders-corporate officers who received private information in the course of their duties-or indviduals who received information from insiders but do not themselves have a duty to the corporation. The latter are known as "tippees," as they received tips from insiders.

The sample is composed of shares from the American Stock Exchange ("AMEX"), the New York Stock Exchange ("NYSE"), NASDAQ, and over the counter ("OTC") markets, which allows for an examination of insider behavior within different market structures. Daily analysis is initially performed to examine whether conclusions drawn in previous literature are idiosyncratic to samples. The analysis is then extended to intraday data to permit examination of trader behaviors both by insiders and uninformed traders as the trades occur.

At the micro level, insider trades are significantly different from surrounding trades in both trade-to-trade price impact and trade lot volume when compared with trades executed in the same thirtyminute interval by other traders. The size and volume effect is most pronounced on the two specialist exchanges, the AMEX and the NYSE. Trade-to-trade price movements are statistically significant at the one-percent level for the panel of NYSE and AMEX shares.

142. See Stanislav Dolgopolov, Insider Trading and the Bid-Ask Spread: A Critical Evaluation of Adverse Selection in Market Making, 33 CAP. U. L. REV. 83,83 (2004).

143. Litigation Releases, U.S. Sec. \& Exchange Commission, https://www.sec.gov/litigation/litreleases.shtml (last updated Oct. 23, 2015). 


\section{Descriptive Statistics}

As Table 1 shows, the sample is primarily driven by insider trades on merger announcements. Merger announcements are perceived as having a greater impact on stock prices than nonmerger announcements simply due to the premium acquirers offer for control of a company.

TABLE 1

\begin{tabular}{|c|c|c|}
\hline Characteristics of Insider Trades & & \\
\hline \multicolumn{3}{|l|}{ Type of Information Traded Upon } \\
\hline & Total & Percent \\
\hline Merger & 23 & $45.10 \%$ \\
\hline Negative Earnings & 5 & $9.80 \%$ \\
\hline Positive Earnings & 6 & $11.76 \%$ \\
\hline Miscellaneous good news & 6 & $11.76 \%$ \\
\hline \multirow[t]{2}{*}{ Miscellaneous bad news } & 11 & $21.57 \%$ \\
\hline & 51 & \\
\hline \multicolumn{3}{|l|}{ Exchanges on which the security traded was listed } \\
\hline & Total & Percent \\
\hline NASDAQ & 35 & $68.63 \%$ \\
\hline NYSE & 14 & $27.45 \%$ \\
\hline \multirow[t]{2}{*}{ OTC } & 2 & $3.92 \%$ \\
\hline & 51 & \\
\hline
\end{tabular}

- indicates significance at a $10 \%$ level

** indicates significance at a $5 \%$ level

***indicates significance at a $1 \%$ level

Table 2 shows that insiders profit more from their trades than those who have been tipped off to the insider information by the insider. This may argue for stronger prosecution of insiders versus tippees, as insiders may trade more adeptly and generate more profit than those who are tipped off. In addition, insiders may be more familiar with how the financial markets react to their company's idiosyncratic results. 
TABLE 2

\begin{tabular}{|c|c|c|c|c|c|c|}
\hline & Mean & Median & $\begin{array}{c}\text { Standard } \\
\text { Deviation }\end{array}$ & Minimum & Maximum & $\mathrm{N}$ \\
\hline $\begin{array}{c}\text { Total } \\
\text { Profit } \\
\text { Gained }\end{array}$ & $178,951.41$ & $59,380.00$ & $369,446.36$ & 340.00 & $2,425,000.00$ & 53 \\
\hline $\begin{array}{c}\text { Total } \\
\text { Loss } \\
\text { Avoided }\end{array}$ & $528,140.35$ & $122,086.50$ & $765,274.47$ & $35,088.08$ & $1,938,465.00$ & 7 \\
\hline & 1.67 & 1.00 & 2.33 & 1.00 & 14.00 & 51 \\
\hline $\begin{array}{c}\text { Number } \\
\text { of } \\
\text { Securities } \\
\text { Traded }\end{array}$ & $86,612.50$ & $553,313.86$ & $-16,683.45$ & $2,425,000.00$ & \\
\hline $\begin{array}{c}\text { Average } \\
\text { Profit/ } \\
\text { Security }\end{array}$ & $278,020.89$ & & & & & \\
\hline & & & & & & \\
\hline $\begin{array}{c}\text { Tippee } \\
\text { profit }\end{array}$ & $100,401.39$ & $58,066.83$ & $96,395.80$ & $1,969.00$ & $259,525.00$ & 22 \\
\hline $\begin{array}{c}\text { Insider } \\
\text { profit }\end{array}$ & $269,082.99$ & $72,594.00$ & $522,243.12$ & 340.00 & $2,425,000.00$ & 38 \\
\hline
\end{tabular}

* indicates significance at a $10 \%$ level

**indicates significance at a $5 \%$ level

***indicates significance at a $1 \%$ level

\section{Intraday Analysis}

Trade-to-trade returns are computed, and then t-tests are performed to measure the difference in insider trade lot sizes and trade-to-trade returns compared to their noninsider peers in the same thirty-minute interval. T-tests are also used to determine statistical significance of means of insider trades lot sizes and returns. The Lee and Ready algorithm is used to determine whether a trade was buyer-initiated or seller-initiated. ${ }^{144}$

The mean and median trade values for the pooled sample of insider trades, as well as the mean and medians for NYSE insider trade lot sizes, fit into Barclay and Warner's definition of "medium sized trades," trades in lot sizes between 500 and 1000 shares. ${ }^{145}$ As Barclay and Warner found medium sized trades to be instrumental to price formation, the insider trades are thus "stealth trades," those trades that move prices but are not immediately noticeable. ${ }^{146}$ Insider trades are found to be statistically different from surrounding trades in terms of price movement, as displayed in Table 3.

144. Lee \& Ready, supra note 124 , at 745 .

145. Michael J. Barclay \& Jerold B. Warner, Stealth Trading and Volatility:

Which Trades Move Prices?, 34 J. FIN. ECON. 281, 283 (1993).

146. Id. at 282 . 
TABLE 3

\begin{tabular}{|c|c|c|c|c|c|c|c|c|}
\hline Returns & $\begin{array}{c}\text { Average } \\
\text { T2T Return/ } \\
\text { Insider }\end{array}$ & $\begin{array}{c}\text { T- } \\
\text { statistic }\end{array}$ & $\begin{array}{c}\text { Average } \\
\text { T2T Return } \\
\text { Noninsider }\end{array}$ & $\begin{array}{c}\text { T- } \\
\text { statistic }\end{array}$ & Difference & $\begin{array}{c}\text { T- } \\
\text { statistic }\end{array}$ & $\begin{array}{c}\text { Z- } \\
\text { Statistic }\end{array}$ & $\begin{array}{c}\text { p- } \\
\text { value }\end{array}$ \\
\hline Mean & 0.0015 & $2.14^{*}$ & 0.0001 & 0.16 & 0.0015 & $4.78^{* *}$ & $3.42^{* * *}$ & 0.0004 \\
\hline Median & 0.0001 & 0.07 & 0.0000 & 0.00 & 0.0001 & 0.17 & $3.86 * *$ & \\
\hline $\begin{array}{c}\text { Standard } \\
\text { Error }\end{array}$ & 0.0007 & & 0.0004 & & 0.0003 & & & \\
\hline $\begin{array}{c}\text { Difference } \\
\text { between } \\
\text { opening } \\
\text { price and } \\
\text { trading } \\
\text { price (in } \\
\text { percent) }\end{array}$ & Insider & $\begin{array}{c}\text { T- } \\
\text { statistic }\end{array}$ & Noninsider & $\begin{array}{c}\text { T- } \\
\text { statistic }\end{array}$ & Difference & $\begin{array}{c}\text { T- } \\
\text { statistic }\end{array}$ & $\begin{array}{c}\text { Z- } \\
\text { statistic }\end{array}$ & $\begin{array}{c}\text { p- } \\
\text { value }\end{array}$ \\
\hline Mean & $0.10 \%$ & 0.55 & $0.07 \%$ & 0.33 & $0.03 \%$ & -1.40 & $2.04 * *$ & 0.0414 \\
\hline Median & $0.00 \%$ & 0.02 & $0.01 \%$ & 0.04 & $0.00 \%$ & 0.21 & 0.04 & \\
\hline $\begin{array}{c}\text { Standard } \\
\text { Error }\end{array}$ & $0.19 \%$ & & $0.21 \%$ & & $-0.02 \%$ & & & \\
\hline
\end{tabular}

- indicates significance at a $10 \%$ level

* indicates significance at a $5 \%$ level

*** indicates significance at a $1 \%$ level

Despite the statistical significance of returns, there is no economic sign in this outcome given the very marginal trade-totrade price changes. (The average insider trade-to-trade return is zero, when rounding to two decimal points.) This Article proceeds to examine whether insider trades are statistically different from surrounding trades in the same thirty-minute interval in terms of both lot sizes traded as well as trade-to-trade price movements.

Aggressive insiders would be expected to utilize market orders to ensure maximum likelihood of execution. Therefore, drawing on the theory that a specialist reacts to the presence of an informed trader by increasing the spread and considering the nature of a market order to "walk the book" to execute,147 Table 4 displays median and mean values for trade lots for insider and noninsider transactions within the thirty-minute interval in which the insider transacts.

147. These are not order sizes, but trade lot sizes; an order can be executed in several sequential (or non-sequential, in the case of limit orders) trades. 
TABLE 4

\begin{tabular}{|c|c|c|c|c|}
\hline $\begin{array}{c}\text { Trade Size (shares) } \\
\text { - NASDAQ }\end{array}$ & $\begin{array}{c}\text { Average Trade } \\
\text { Size/Insider }\end{array}$ & $\begin{array}{c}\text { Average Trade } \\
\text { Size/Noninsider }\end{array}$ & Difference & Z-Statistic \\
\hline Mean & 947.36 & 425.38 & 521.98 & 0.34 \\
\hline Median & 363.64 & 348.85 & 14.78 & \\
\hline Standard Error & 225.55 & 92.04 & 133.51 & \\
\hline $\begin{array}{c}\text { Mean as \% of ADV } \\
\text { Median as \% of } \\
\text { ADV }\end{array}$ & 0.0009 & 0.0004 & 0.0005 & \\
\hline $\begin{array}{c}\text { Standard Error as } \\
\text { \% of ADV }\end{array}$ & 0.0003 & 0.0003 & 0.0000 & \\
\hline $\begin{array}{c}\text { Trade Size (shares) } \\
\text { - NYSE \& AMEX }\end{array}$ & $\begin{array}{c}\text { Average Trade } \\
\text { Size//nsider }\end{array}$ & $\begin{array}{c}\text { Average Trade } \\
\text { Size/Noninsider }\end{array}$ & Difference & Z-Statistic \\
\hline Mean & $1,143.66$ & $1,069.53$ & 74.14 & $1.52^{*}$ \\
\hline Median & 500.00 & 329.76 & 170.24 & \\
\hline Standard Error & 327.39 & 278.99 & 48.40 & \\
\hline Mean as \% of ADV & 0.00191 & 0.00179 & 0.00012 & \\
\hline $\begin{array}{c}\text { Median as \% of } \\
\text { ADV }\end{array}$ & 0.00084 & 0.00055 & 0.00028 & \\
\hline $\begin{array}{c}\text { Standard Error as } \\
\text { \% of ADV }\end{array}$ & 0.00055 & 0.00047 & 0.00008 & \\
\hline
\end{tabular}

* indicates significance at a $10 \%$ level

**indicates significance at a $5 \%$ level

***indicates significance at a $1 \%$ level

The difference in the median size of trade lots is not significant at the ten-percent level. However, the difference in the mean lot is significant at the five-percent level. This indicates that while most trades are not noticeably different from surrounding trades, insiders occasionally transact in disproportionately large lots. One could attribute this to naive or foolish insiders skewing the result, although the average insider trades in a more sophisticated manner.

However, as a proportion of average daily volume (calculated over the thirty days prior to the insider trade), insiders' mean transactions represent .01\%; although insiders may occasionally transact in large lots, they by no means represent a large amount of the daily turnover. Thus, it is unlikely that any order imbalance spurs an influx of falsely informed traders seeking to capitalize on what they perceive as a change in valuation fundamentals.

This finding, and the discovery that eight percent of abnormal volume on insider days is unexplained by inside volume, may be consistent with Cornell and Sirri's hypothesis that falsely informed traders enter the market when inside traders are present. ${ }^{148}$ This is also consistent with Fishe and Robe's finding that there is a marginal increase in volume on days that insiders are present-

148. See Cornell \& Sirri, supra note 103, at 1054 . 
$9.2 \%$ in their case, ${ }^{149} 8 \%$ in the case of this examination. This behavior may also be due to daily trend followers and momentum traders entering the market when perceiving that there is increased activity.

This Article proceeds to test the nature of trade-to-trade returns on the NYSE, AMEX, and NASDAQ relative to peer trades in the same thirty-minute interval to discern whether insiders spur price changes in an abnormal fashion or if they are indistinguishable from liquidity traders. It has been inferred that a specialist will increase the spread in the presence of an informed trader, 150 and therefore one would expect specialist-based exchanges such as the NYSE and AMEX to have a higher price change than a dealer exchange such as NASDAQ, as the specialist is able to detect the presence of the informed trader and will thus raise the spread.151

An overall look at intraday returns in Table 5 shows that the returns to insider trades are highly significant only in the case of the NYSE, with a $t$-statistic of 2.85 , leading to significance at a onepercent level.: Therefore, the hypothesis that insider trades on the NYSE are statistically significantly different from surrounding trades in terms of trade-to-trade price movements is not rejected. The hypothesis that NASDAQ insider trades are not statistically significantly different from surrounding trades in terms of price-toprice movement is also not rejected. Lot sizes are statistically insignificantly different from surrounding trades under all market structure regimes.

TABLE 5

\begin{tabular}{|c|c|c|c|c|}
\hline $\begin{array}{c}\text { Returns } \\
\text { (NASDAQ) }\end{array}$ & $\begin{array}{c}\text { Average T2T } \\
\text { Return/Insider }\end{array}$ & $\begin{array}{c}\text { Average T2T Return } \\
\text { Noninsider }\end{array}$ & Difference & Z-Statistic \\
\hline Mean & 0.00176 & -0.00003 & 0.00179 & 1.62 \\
\hline Median & 0.00003 & 0.00000 & 0.00003 & \\
\hline Standard Error & 0.00099 & 0.00046 & 0.00053 & \\
\hline & & & & Z-Statistic \\
\hline $\begin{array}{c}\text { Returns (NYSE } \\
\text { \& AMEX) }\end{array}$ & $\begin{array}{c}\text { Average T2T } \\
\text { Return/Insider }\end{array}$ & $\begin{array}{c}\text { Average T2T Return } \\
\text { Noninsider }\end{array}$ & Difference & $2.85^{* * *}$ \\
\hline Mean & 0.00110 & 0.00025 & 0.00085 & \\
\hline Median & 0.00013 & 0.00000 & 0.00013 & \\
\hline Standard Error & 0.00025 & 0.00032 & -0.00007 & \\
\hline
\end{tabular}

* indicates significance at a $10 \%$ level

**indicates significance at a $5 \%$ level

***indicates significance at a $1 \%$ level

149. See Fishe \& Robe, supra note 129, at 463.

150. Lawrence M. Benveniste, Alan J. Marcus \& William J. Wilhelm, What's Special About the Specialist?, 32 J. Fin. ECON. 61-86 (1992); Glosten \& Milgrom, supra note 90 , at 71 .

151. Benveniste, Marcus \& Wilhelm, supra note 150, at 61-86. 
This Article discovers that insider trades do on average possess attributes that differentiate them from surrounding trades, but a great deal of those attributes depend on the trade characteristicsaggressive market orders will draw scrutiny due to their price impact, whereas limit orders are less noticeable. The lot sizes of inside trades are sometimes larger than those of other market participants at the time, thereby potentially drawing attention from regulators and surveillance departments.

The results confirm the anonymity hypothesis of Glosten and Milgram, ${ }^{152}$ displaying the strong impact of the specialist in regulating fluid market performance. However, insider trading on NASDAQ is significant, yet not to the degree that it is on specialist markets, due to the ability of the specialist to protect herself against uncontrolled loss to the insider.

An investigation of this impact using foreign markets with similar structures would be of interest. The results further imply that order type matters, but without a database of illegal insider trades sorted by order time, one cannot confirm this hypothesis. In addition, characteristics of the insider, such as profession, may affect their trading practices.

\section{CONCLUSION}

The law and economics of insider trading continue to develop. On the legal side, there has been pressure to clarify and shore up the legal framework. Insider trading laws have been criticized for being ambiguous and needing clarification. While ambiguous laws may be easier to enforce by the government, the courts have shown discomfort with the gray areas of insider trading laws and have handed the government many defeats. On the economics side, there has been work done to examine the impact of insider trading on the markets.

This Article contributes to both these sides, and it offers an empirical examination of the impact of insider trading on market performance and price distortion. This Article finds that trades are different from surrounding trades in both trade-to-trade price impact and trade lot volume, information that should aid the government in identifying and prosecuting insider trading.

However, more work needs to be done in both the legal and economics realms to clarify and identify insider trading. In the meantime, the government will continue to have unpredictable successes and failures in prosecuting insider trading.

152. Glosten \& Milgrom, supra note 90 , at 71. 
*** 